\title{
Language Style in the Legendary Book Les Plus Belles Histoires et Les Legendes de France
}

\author{
${\text { Hesti Fibriasari }{ }^{1 *} \text {--- Nurazizah }}^{2}$ \\ ${ }^{1,2}$ Department of French Language Education, Universitas Negeri Medan, Medan, Indonesia. \\ Email:hesti@unimed.ac.id
}

\begin{abstract}
Language style is a way of expressing thought in language so that the character and capacity of an author are implied in using language. So the purpose of this study is to analyze what style of language was used in the traditional book entitled "Les Plus Belles Histoires et Les Légendes de France" edition of Morena and to find out the type of language style which is most widely used by the authors in the book. The types of language styles that will be analyzed are the type of Repetition, Hyperbole, Metaphor, Personification, and Comparison. This study used the descriptive qualitative method which means that the conclusion of this study will be written in sentences form. The source of this study is a legendary book entitled "Les Plus Belles Histoires et Les Légendes de France." Based on the results of the research that has been done, all types of language styles analyzed were found in that book, namely: Repetition 7, hyperbole 15, metaphor 17, personification 11 and comparison 34. From the results of this study, it can be concluded that the type of language style which is most widely used by the author is the Comparison type.
\end{abstract}

Keywords: France book, Language style, Legend, Metaphor, Repetition, Hyperbole, Personification, Comparison. Licensed: This work is licensed under a Creative Commons Attribution 4.o License.

Funding: This study received no specific financial support.

Competing Interests: The authors declare that they have no competing interests.

\section{Introduction}

Language style or figure of speech is part of the language that does not become so important when the language is parole, but it can be a marker given by an author in his writing to make his work has its style or character. Literary works writers use the figure of speech in writing to express their ideas in exciting ways. Nasution (2014) says that the figure of speech causes literary works to attract attention, create freshness, live more, and create clarity of imagination. This means that the figure of speech can create an impression that it looks new to make it more interesting to read.

Writing or literary works that use a lot of figures of speech to lull the reader as if they are in it and feel that the story exists in the real world where the story was told because of an evident imagination, such as poetry, tales, legends, stories of society, and history. In Indonesia, there is the story of Sangkuriang or the history of Giliraja, and in France, there are par exemple la légende de La Belle Madeleine, La Coquette Punie, Le Curé Avisé, etc.

Although it becomes more interesting, if a reader does not know the concept of interpreting a message, it will create a bias for him when understanding the story or increasing false impressions on the writing. Therefore, in this research, the author will explore the concept of direct figures of speech through traditional books. The legendary book used as the object of study was a typical French book entitled "les plus belles histoires et les légendes de France" edition of Morena. This book was chosen because this book is a wellknown book and has high expectations from the author, when the learner, in this case, is French students, understanding how to interpret figure of speech will increase their reading interest in history and add knowledge about the use of language forms or figure of speech. 


\section{Language Style}

Language style is the process of managing language to show its peculiarities, to highlight its efficiency, or to create courage or resentment with more or less strongly depending on the choice of words used, sentence setting, selection of a term or combination of certain words (Beth, 2005).

One characteristic of human language can find itself, through the style of language that is used as a possible measuring tool because the language style is used every day, for example when someone says «j'ai dix mille chooses à faire», ou «il nous a quittés» According to Raymond Queneau's research, there is a different way to define the sentence. This condition shows unlimited language interpretation, and how the form is chosen can have an impact on the perception and understanding that will be made by the reader.

\subsection{Comparison}

This thing is the figure of speech that is used to compare two elements. This figure of speech makes it possible to establish a relationship between two terms together with the assistance of conjunctions. A comparison is like a reflection of two elements (words or phrases) that both of them are used to present a more concrete, explicit, and more sensitive state of affairs for compelling et un terme les reliant, appelé comparative (tel, comme, ainsi que ...).

Par exemple: Si je le théâtre essentiel est comme la peste, ce n'est pas parce qu'il est contagieux, mais parce que comme la peste il est la révélation, la mise en avant, la poussée vers l'extérieur d'cruauté latente par lequel as local as possible, individual, un peuple toutes les possibilites perverses de l'esprit (Beth, 2005).

In the example above, Artaud used a comparison between la peste et le théâtre. He used the connotation associated between plague and drama to release a very real description from the part of the shadow that he projects to come to the theater.

\subsection{Metaphor}

The metaphor is a figure of speech which compares two elements without comparison tool. This term is taken figuratively. The metaphor compares comparators with those compared. This case cannot be called a comparison like the first type because metaphor creates links that implicitly unite.

Example: My courage, don't forget that little emotions are the great captains in our life and they obey them without realizing it (Beth, 2005).

In this quote from a letter to his brother Théo, Van Gogh uses a military image to illustrate the power of emotion although it is small <ces petits émotions>. This thing is an implicit comparison: there is no comparison compared. It only implies a metaphor: because of the power of contrast with the military situation, which means the little emotion becomes an indisputable grip of our life. (Even the smallest feeling to fight will lead us to face the war that will make the opponent unconsciously follow our role. Same with life, emotions must be used as courage to face life without others know they will support our desires).

\subsection{Repetition}

Repetition is sound repetition, syllables, words, or parts of words that are considered essential to put pressure in the right context (Keraf, 2007). According to Axelle Beth when we talk about repetition when the word is repeated several times and the repeated words are separated in sentence or text, so the repetition is used to show the quantity, or show the main idea or idea as well as aesthetics.Exemple : La justice sans la force est impuissante ; la force sans la justice est tyrannique. La justice sans force est contredite, parce qu'il y a est tyrannique. La justice sans force est contredite, parce qu'il y a toujours des méchants ; la force sans la justice est accusée. Il faut donc mettre ensemble la justice et la force ; et pour cela faire que ce qui est juste soit fort, ou que ce qui est fort soit juste.

\subsection{Personification}

Personification is the process of presenting an object or idea as a human being, namely a figure of speech that closes inanimate objects with humans. This thing represents something or an idea in someone's guise. It means that personification is an allegory that uses the human character with non-human objects. 2005).

Par exemple : un soir j'ai assis la Beauté sur mes genoux. Et je l'ai trouvée amère, et je l'ai insultée (Beth,

The personification of la Beauté: This presents a living concept (using capital letters). This process, in addition to poetry discourse, also shows the familiarity of the poet with la Beauté and his iconoclastic desire to destroy existing moral values. There are also some who interpret it as a woman's image and heterosexual disappointment from Rimbaud.

\subsection{Hyperbole}

Hyperbole is excessive. This case is a theme that is used to produce a strong impression. Hyperbole uses terms whose meaning is too strong concerning the reality being offered.

Par exemple: Je t'ai appelé mille fois. (Pramuniati and Sa'dah 2011)

The word mille fois is impossible for someone to be able to say it for a thousand times, but this implies that he has said it many times, but no one listens to it. 


\section{Methodology}

The researchers used methods in research to find out how to do this research and what ways can be done in this study. Widodo (2002) stated a qualitative methodology as a research procedure that produces descriptive data in the form of written or oral words from people and observable behavior. Therefore, this study will use the writing sentence to explain the data obtained in this study. The object of this study uses French legends and analyzes some forms of language style contained in them. This study uses library search methods or data obtained by reading literature books that are suitable for this problem. Analyzing data in this research is needed to solve research problems.

The analysis technique used is descriptive qualitative technique. The research procedure is as follows. First of all, find out what type of language was found in the book "Les plus belles histoires et les légendes de France." Then, read the book "Les plus belles histoires et les légendes de France carefully". After that, search fo figures of speech contained in the book "Les plus belles histoires et les légendes de France ", analyze the figures of speech found, identify the type of figures of speech that were found, then classify them, after that conclude the figures of speech the book" Les plus belles histoires et les légendes de France ".

\section{Results and Discussion}

This chapter will show the results of research that have been done to answer the problem formulation in the first chapter. In this study, the author has identified five forms of figures of speech. Ce sont l'hyperbola, la répetition, la métaphora, la personification et la comparison. The result of the analysis can be summed up on the Table 1:

Table-1. Five forms of figures of speech in France Legendary book

\begin{tabular}{c|l|c|c}
\hline No & The analyzed style figures & Frequence & Percentage (\%) \\
\hline 1 & La répétition & 7 & 8 \\
\hline 2 & L'hyperbole & 15 & 17 \\
\hline 3 & La métaphore & 17 & 22 \\
\hline 4 & La personification & 11 & 13 \\
\hline 5 & La comparaison & 34 & 40 \\
\hline Total & 84 & 100 \\
\hline
\end{tabular}

The figures of speech that have been classified in the table above are 7 cases in la répétition, 15 cases in l'hyperbole, 17 cases in la métaphore, 11 cases in la personnification and 34 cases in la comparaison.

\section{Conclusion}

Based on the research carried out in the history books "les plus belles histoires et les légendes de France," there are all types of figures of speech identified therein. Figures of speech which have been classified in the table above are 7 cases in la répétition, 15 instances in l'hyperbole, 17 cases in la métaphore, 11 cases in la personnification and 34 cases in la comparaison.

The most common type of figure of speech is the comparison, with 34 cases. This happened because in the legend there are many comparisons between the life that is told and the actual life today, including the use of comparison between animals and humans, human activities with the wind, a rich king in the sea, a poor man who shakes leaves, etc. This indirectly imagines how history happened.

\section{References}

Beth, A. \& Marpeau, E. (2005). figures of style. Paris: E.J.L.

Keraf, G. (2007). Language and language style. Jakarta: PT Gramedia Main Library.

Nasution, H.T. (2014). Analyzes the figure of speech on the novel of S.O.S., Jura in danger. Memory. Medan: UNIMED.

Pramuniati, I. \& Sa'dah, W. (2011). Text study. Medan: UNIMED.

Widodo, J. (2002). Research methodology. Public policy: Reading. New York: New Jersey. 